\title{
The Dynamics of Food Fraud: the interactions between criminal opportunity and market (dys)functionality in legitimate business
}

DOI:

$10.1177 / 1748895816684539$

\section{Document Version}

Accepted author manuscript

Link to publication record in Manchester Research Explorer

Citation for published version (APA):

Lord, N., Flores Elizondo, C. J., \& Spencer, J. (2017). The Dynamics of Food Fraud: the interactions between criminal opportunity and market (dys)functionality in legitimate business. Criminology and Criminal Justice, 17(5), 605-623. https://doi.org/10.1177/1748895816684539

\section{Published in:}

Criminology and Criminal Justice

\section{Citing this paper}

Please note that where the full-text provided on Manchester Research Explorer is the Author Accepted Manuscript or Proof version this may differ from the final Published version. If citing, it is advised that you check and use the publisher's definitive version.

\section{General rights}

Copyright and moral rights for the publications made accessible in the Research Explorer are retained by the authors and/or other copyright owners and it is a condition of accessing publications that users recognise and abide by the legal requirements associated with these rights.

\section{Takedown policy}

If you believe that this document breaches copyright please refer to the University of Manchester's Takedown Procedures [http://man.ac.uk/04Y6Bo] or contact uml.scholarlycommunications@manchester.ac.uk providing relevant details, so we can investigate your claim.

\section{OPEN ACCESS}


Lord, N., Flores Elizondo, C. and Spencer, J. (in press) 'The Dynamics of Food Fraud: the interactions between criminal opportunity and market (dys)functionality in legitimate business', Criminology and Criminal Justice. Accepted for publication 17 October 2016

\title{
The Dynamics of Food Fraud: the interactions between criminal opportunity and market (dys)functionality in legitimate business
}

\author{
Nicholas Lord, Cecilia Flores Elizondo and Jon Spencer \\ Centre for Criminology and Criminal Justice \\ University of Manchester
}

Abstract - This article conceptualises 'food fraud' by shifting analytical focus away from popular/policy conceptions foregrounding the centrality of organised crime towards understanding the factors that shape the organisation of food frauds. We argue that food fraud, rather than being an 'exogenous' phenomenon perpetrated by externally organised (transnational) 'criminal enterprise', is better understood as an 'endogenous' phenomenon within the food system where legitimate occupational actors and organisations are in some way necessarily involved. Criminal opportunities arise under conducive conditions as part of legitimate actors' routine behaviours. Our contention is that the common definition of food fraud is too prescriptive and fails to allow space to understand the role of different actors and their motivations. We analyse a case study in soft drinks, presenting the necessary role of legitimate, occupational actors within/between legitimate organisational settings and markets, and demonstrate how criminal behaviours can be concealed and disguised within 'ready-made' market and business structures.

Keywords - food fraud; organisation of crime; occupational crime; organisational crime; white-collar crime; organised crime 
'The violations in the Detroit wholesale meat industry were committed by persons more or less well established in the different levels of the industry, from slaughterers to processors to wholesalers and to peddlers. It is this fact which, to a greater extent than any other, leads to the conclusion that the established businessman or firm was the black-marketeer. The importance of this for a general theory of criminality is great' (Hartung, 1950: 29)

\section{Introduction}

This article has one central objective: to conceptualise the debate around 'food fraud' by shifting analytical focus away from popular and policy conceptions that foreground the centrality of organised crime towards understanding the factors and conditions that shape the organisation of food frauds in the food system. With few notable exceptions (see Croall, 2007, 2010, 2012; Spink and Moyer, 2011; Manning et al., 2015), 'food crimes' have not received any substantive attention from the criminological or academic community. Instead, the phenomenon of food fraud is commonly understood and portrayed as a problem of external 'organised crime groups' operating transnationally that undermine the integrity of the otherwise robust UK food supply system:

'Experts within the horse slaughter industry have told The Observer there is evidence that both Polish and Italian Mafia gangs are running multimillion-pound scams to substitute horsemeat for beef during food production' (Observer, 2013)

This theme of organised crime is also visible in other media publications, for example 'Crime gangs expand into food fraud' (Guardian, 2014 ${ }^{1}$ ); 'Organised gangs have a growing appetite for food crime' (Economist, 2014 ${ }^{2}$ ); and finally, 'Organised crime is switching to food fraud from activities such as drug trafficking, because detection methods are less developed and penalties are softer' (Food

\footnotetext{
${ }^{1}$ http://www.theguardian.com/world/2014/may/03/crime-gangs-target-food-fraud-draft-eu-report

${ }^{2}$ http://www.economist.com/news/britain/21599028-organised-gangs-have-growing-appetite-food-crime-lacartel
} 
Manufacture, $2011^{3}$ ). Similarly, the EU and domestic UK policy agenda has remained preoccupied with focusing on the economically motivated, goal oriented activities of organized crime groups to produce and distribute fraudulent food products as part of an increasingly attractive business enterprise (see SOCTA, 2013; EU Council, 2014; Elliot Review, 2013). However, contrary to these popular conceptions, there appears to be no consistent pattern of the involvement of organised crime in food fraud and in the UK the National Food Crime Unit (NFCU) makes clear that their 'gathered intelligence has not evidenced a substantial role for organised crime within food criminality' (NFCU, 2016: 22). Thus, as Hartung (1950) concluded over 60 years ago in relation to criminality in the Detroit meat industry, we must reorganise our thinking to understand the central role of legitimate, occupational actors in the organisation of food frauds.

We argue that food fraud, rather than being an 'exogenous' phenomenon perpetrated by (transnational) organised crime groups and 'criminal gangs' seeking to permeate the food supply chain, is better understood as an 'endogenous' phenomenon within the food system where criminal opportunities arise under conducive/facilitative conditions as part of legitimate actors' routine behaviours. This conception of 'food fraud' recognises the interplay between the motivations of various actors, and their social/criminal networks, to 'make the most of' fraudulent opportunities that arise. Generally, this is under conducive situational settings, for example within particular businesses where non-compliant practices may in some instances be 'acceptable' and within facilitative market and industry structures and cultures. Furthermore, we acknowledge the necessary role of legitimate actors in the food supply chain as integral to the occurrence of food fraud, rather than organised crime groups, whose involvement in the UK food system is likely to be more contingent. We argue that the illicit behaviours, relations and transactions in many food fraud cases are organised and concealed within legitimate markets. Little is known about how, why and

${ }^{3}$ http://www.foodmanufacture.co.uk/Ingredients/Criminals-drop-drugs-for-food-fraud 
under which conditions such food frauds are organised, or about how motivated offenders organise their behaviours to realise these opportunities that arise at particular times and in particular places.

To explore the dynamics of food fraud we provide a case study of the soft drinks market. We undertake an analysis of the tampering of Best Before Dates (BBDs) of a popular sports drink in order to better understand the range of crime scenes, actors involved, and their required resources, skills and knowledge. We analyse the actions and decisions throughout the fraud commission process in relation to the networks of cooperating actors involved and the market and industry conditions that are conducive to these behaviours. This case study is one of a range of cases analysed as part of an ESRC/Food Standards Agency (FSA) funded project that aims to understand the challenges of the food system. We present the soft drinks analysis as a means to illustrate key themes, features and issues emerging out of and common across these varied food chains. Although we present the analysis of one specific case study, it is our contention that the arguments in relation to the soft drinks market are valid to analogous cases ${ }^{4}$. The central features in the case study are also applicable to other supply chains in the UK and other countries and the global food system more generally. We argue there are common cultural, market, industry and organisational features, practices and structures providing opportunities for fraud that are also evident at a higher level of generality within other food markets and systems.

The article begins with a discussion of 'food fraud' as an emerging policy and scientific construct at the domestic and international levels. We argue for utilising social scientific understandings and approaches to the phenomenon to move away from narrowly conceptualised notions of the nature of the problem and those involved. An over-emphasis on 'organised crime' gives too little attention to industry players. Throughout we foreground the central and embedded role of legitimate supply

\footnotetext{
${ }^{4}$ That is, in line with principles of moderatum generalisation where aspects/features of a given case can be seen to be instances of a broader recognisable set of features (see Williams, 2000)
} 
chain actors and businesses in the commission and facilitation of food frauds in the context of market fragmentation and market dysfunctionality. We conclude by arguing that we can better understand food fraud as an endogenous phenomenon within legitimate food production and supply chains.

\section{Conceptualising 'food fraud': an emerging policy and scientific construct}

Despite food fraud having a long history (see Shears, 2010), it is a concept that has not gained currency as a major global policy issue and remains poorly conceptualised, but more recently it has begun to gain some traction as a policy construct. Given the emerging importance of food fraud it is necessary to have a clear concept of what is meant by the term as 'concepts constitute social problems and they can have multiple meanings for policy-makers and social scientists' (Edwards et al., 2013: 260). It is important to establish common referents in relation to food fraud as this ensures domestic and inter-national political and scientific actors are able to enter into coherent debate and dialogue over the nature of the problem and how better to respond. With this in mind it is necessary to formulate a social scientific understanding of 'food fraud' that resonates with the policymaking and practitioner communities.

To define 'food fraud', it is helpful to first consider what is meant by fraud. Fraud is a 'deceptively simple word covering a very broad territory. It is a way of making money illegally via deception...[and] there is a huge range of contexts in which frauds, large and small,...are perpetrated' (Levi, 2012: 7). However, the wide range of behaviours encompassed by 'fraud' makes developing a definitive concept difficult. For Doig (2006: 20),

'[i]t could be argued that one of the reasons why there is no single definition or offence [the Fraud Act 2006 now covers the latter] of "fraud" is because much of the attention is on a process...Indeed, the purpose of fraud is not the process itself but the acquisition or gain that it is intended to achieve'. 
This directs us to both processes (i.e. deception) and outcomes (i.e. monetary gain). In the Fraud Act $2006^{5}$ the general offence of fraud is defined in terms of how it is committed - by a dishonest false representation, by a dishonest failure to disclose information when there is a legal duty to do so, and by a dishonest abuse of position. The Act further stipulates that in each case, the actor intends to make a gain for himself [sic] or another, or intends to cause loss to or to expose another to a risk of loss.

Central to both sociological and legal constructs is the concept of dishonesty and also a criminal intent to gain or cause loss. These concepts, in addition to the deceptive behaviours intrinsic to attempts to 'persuade somebody to part with something' (Doig, 2006: 19), we argue must be central to the definition of food fraud. This broad framing clearly incorporates a very wide array of illicit behaviours, practices and transactions in addition to a very wide array of 'criminal' actors, and this is relevant in the development of 'food fraud' at the policy level.

As a policy construct at the European level, the concept remains underdeveloped and has only recently emerged on the political agenda. Supranational organisations, such as the EU, are progressively concerned that there is an increase in the number of food fraud incidents and that this trend reflects a structural weakness within the food chain (European Parliament, 2013: 5). However, until an agreed conceptual framework is in place, the different approaches of Member States and their divergent principles and frameworks remain to the fore. As a policy construct at the domestic level, the Food Standards Agency (FSA), the UK regulator responsible for food safety, provides the most current definition of food fraud in the UK. In 2007 the Food Fraud Task Force that was hosted within the FSA explained food fraud as follows:

\footnotetext{
${ }^{5}$ http://www.legislation.gov.uk/ukpga/2006/35/contents
} 
'Under the Food Safety Act 1990, if a person is deliberately supplied with a food commodity that is not of the nature, substance or quality demanded or is unsafe and the supplier does so with the intention of gaining financially from the act, then food fraud has occurred. The food fraud may have public health implications if the food is unfit or contaminated and likely to give rise to illness in the consumer, or economic implications if a person receives a commodity of a lower standard than expected. Both aspects may also occur together' (Food Fraud Task Force, 2007: 15)

We see commonalities here with the general definitions of 'fraud' and it is this framework that guides the current FSA discourse, where it is argued that food fraud is 'committed when food is deliberately placed on the market, for financial gain, with the intention of deceiving the consumer...[T]he two main types are: the sale of food which is unfit and potentially harmful...[and]...the deliberate misdescription of food' (2016: website ${ }^{6}$ [emphasis added]). This definition incorporates assumptions over the motivations of those actors involved in food fraud. Framing food fraud in these terms is simplistic as binary constructions of food fraud obscure the heterogeneous motivations, decisions, behaviours and conditions that lead to such frauds. Furthermore, proving 'intent' or 'deliberateness' is likely to present major obstacles to regulators and the criminal courts when having to demonstrate evidentially that the adulteration, or mislabelling, and other fraudulent behaviour, was not accidental. The academic literature has broadly-construed food fraud as an intentional, deliberate act for economic gain:

'Food fraud is a collective term used to encompass the deliberate and intentional substitution, addition, tampering, or misrepresentation of food, food ingredients, or food packaging; or false or misleading statements made about a product, for economic gain' (Spink and Moyer, 2011: 158).

Spink and Moyer also focus on 'economically motivated adulteration' (EMA) as a subset of food fraud defined as '...the fraudulent, intentional substitution or addition of a substance in a product for the purpose of increasing the apparent value of the product or reducing the cost of its production' (Spink and Moyer, 2011: 157-8, citing the US Food and Drugs Administration (FDA)).

6 FSA website: http://www.food.gov.uk/enforcement/enforcework/foodfraud/\#Whatisfoodfraud? 
Such constructions of the problem rely on assumptions of 'economic rationality'. However, this risks conflating individual and organisational/business gains and motivations, assumes 'offenders' understand that their activities are illegitimate, and does not sufficiently recognise the structural, organisational and cultural forces that shape individual behaviour under particular conditions (see for instance Vaughan, 1998, 2007). The occupational and organisational settings of actors working in the food supply chain can create cultures where certain deviant behaviours are normalised in order to achieve organisational cultures and goals. Similarly, employees may experience organisational pressure to go along with fraud for fear of losing their job. These 'human factors' create problems for the applicability of conventional economic rational choice theories.

Despite these limitations, it is this approach that has shaped academic inquiry into food fraud. One consequence is that we have witnessed the emergence of the concept of food fraud guided by state definitions based on normative judgements. Contributing to this approach is scientific food fraud scholarship where we see arguments in favour of testing technologies and the authenticity assurance of products as a counter to fraudulent practice, but such approaches can only identify that food adulteration has occurred at an unknown point earlier in the production chain (i.e. after the fact) (see for instance Woolfe and Primrose, 2004; Ellis et al., 2015). No doubt such post-fraud detection measures are useful, but understanding the nature and organisation of the behaviours involved in how, when and where food fraud actually occurs, ought to be a key aim of prevention efforts. But there is a dearth of social scientific empirical analyses of socially embedded human behaviours in the area of food fraud.

\section{Establishing a social scientific conception of 'food fraud'}

A useful framework to avoid the mistake of seeing fraud, and food fraud, always as part of a conscious, pre-conceived strategy of deception, is evident in Levi's (2008a; 2008b) threefold 
typology of fraud (developed in relation to 'long-firm fraud' specifically) where we can see the utility of looking at food fraud as a:

1) pre-planned fraud, where a food fraud activity or scheme is set up from the start with the intent of defrauding victims (e.g. other businesses, individuals, the state)

2) intermediate fraud, where people start out obeying the law but consciously turn to food fraud later (likely as a response to a particular event or state or condition)

3) slippery-slope fraud, where deception spirals, often in the context of trying, whether absurdly or over-optimistically, to ensure that a business does not go bankrupt or cease trading.

Each of these underlying motivations involves intent at some point and each can involve different fraudulent 'processes'. The key argument to take from this typology is that 'motivation to defraud can be heterogeneous rather than a single phenomenon' (Levi, 2008b: 394) and the goal may indeed be to profit financially but in other cases this may be a secondary outcome as actors in the supply or production chain seek to maintain their business. Some food frauds may not be pre-planned but may be located on a 'slippery-slope' of actions such as when market pressures and structures combine to create conditions under which businesses are left with large surpluses and a saturated market, although a pre-planned fraudster may seek to construct themselves as on a 'slippery-slope'. Thus, a wide range of motivated, 'entrepreneurial' actors with varying levels of reputability and legitimacy can be implicated in food frauds including large, global corporate and industry players (see Tombs and Whyte, 2015), middle range businesses in farming and food production (see Croall, 2010) as well as 'rural rogues' at the lower end of the food system (see Smith, 2004). In addition, while motivations may vary together with fraudulent processes, the outcomes for those defrauded and deceived, whether consumers, other businesses or the state, can take the form of varied financial or physical harms. Thus, food fraud always involves at some stage deliberate dishonesty to obtain an advantage from or cause losses to or harms against individuals (e.g. consumers), groups (e.g. companies, market actors and investors), or the state (e.g. tax and revenue). In this sense, we can 
distinguish intentional frauds from a range of behaviours and regulatory violations that are often conceptualised as 'non-compliance', such as carrying out inadequate due diligence on suppliers, or 'lawful but awful' (see Passas, 2005), such as unethical advertising 'selling' packaged products as the dream including sugary drinks to children or misleading pictorial representations of supposedly local farms and produce to entice customers. Some would also include food poisoning as a form of food crime against consumers, made possible and produced by profit-making corporations and their standards violations (Tombs and Whyte, 2015: 41-45) - though such behaviours remain outside of the criminalised sphere due to the lack of criminal intent. That said, while the conception of 'deliberate dishonesty' is necessarily closely aligned to the definition of fraud, particularly for the purposes of prosecution, 'lawfully' dishonest behaviours across the market institutionalise noncompliant behaviours and conducive conditions for 'sliding' into food fraud.

We conceptualise food fraud as relating to the abuse or misuse of an otherwise legitimate business transaction and an otherwise legitimate social/economic relationship in the food system in which one or more actors undertakes acts or omissions of deception or dishonesty to avoid legally prescribed procedures (process) with the intent to gain personal or organisational advantage or cause loss/harm (outcome). This definition incorporates a variety of fraudulent behaviours such as adulteration, mis-labelling, and mis-description, amongst others, and reinforces how food fraud is an endogenous phenomenon of the legitimate food system. What is more, this definition enables us to shift away from constructs that are preoccupied with trying to identify what 'it' looks like towards understanding the nature and organisation of the processes, behaviours, relations and actors involved. Seeking to understand defining features and/or characteristics of those (organised crime) groups that undertake them is the wrong analytical question. A more pertinent question is to ask what factors and conditions over time shape the ways in which particular forms of food fraud are organised and who, beyond the direct perpetrators, gets involved in them (see Levi, 2007: 779, for analogous discussion of organised crime and fraud more generally). 
There are two further sets of related issues that need to be acknowledged that are concerned with the regulation of 'food fraud' offences and the corporatisation of the industry. First, our current research suggests that strategies of enforcement are not uniform across the sector as there are powerful vested interests within the food sector. It appears that in some cases an 'Al Capone' approach is taken, that is prosecuting for an administrative offence, for example, lack of an adequate audit trail or a failure to carry out minimum due diligence. In other cases where the interests are not so apparent there is a more robust approach to enforcement. There are also marketing practices which are not illegal, and yet do seem to convey certain attributes to the food in question, that may be problematic to substantiate. Second, large businesses are increasingly dominating the food industry and food sectors leading to the corporatisation of production and distribution in addition to market dominance through ownership structures and market shares (e.g. the supermarket sphere is dominated by four main companies while certain products and brands are owned by the same companies). These structures and forces create potentially criminogenic markets and conditions (this has long been recognised in the criminological literature: e.g. Faberman (1975) in relation to the automobile industry; and, Braithwaite (1984) in relation to pharmaceuticals).

\section{The 'Organisation of Food Fraud', not 'Organised Crime and Food Fraud'}

Popular policy conceptions frame food fraud as an external problem of organised criminal networks and enterprise. It is politically convenient to construct a dominant narrative that presents the food system and food supply chains as otherwise robust and with a high level of integrity, or at least seek to construct a 'strict separation between legitimate (British) retailers, processors and producers and the criminal elements that exist further down the supply chain' (Tombs and Whyte, 2015: 32). In this regard, the recurrent distinction within the white-collar crime literature between the construction of violations as either 'regulatory' (i.e. mala prohibita) or 'criminal' (i.e. mala in se) in nature is subsequently associated with the transgressions of 'big business' and 'small business' respectively. 
Consequently, attention is diverted away from the activities of implicated (global) corporate players towards small and medium sized supply chain actors that are more susceptible to permeation by external organised crime groups or where a lack of due diligence or criminal intent is more readily established by the prosecuting authorities.

Furthermore, presenting food fraud as associated with external organised crime groups, often from Eastern European jurisdictions, maintains consumer confidence in local markets and offers protection to retailer reputation. For instance, policy initiatives at both the supranational and domestic levels have framed 'food fraud' and 'food crime' as a problem associated with 'organised crime'. For example, the 2013 EU Serious and Organised Crime Threat Assessment (SOCTA) stated that '[i]n addition to the traditional counterfeit luxury products, [organised crime groups] now also counterfeit daily consumer goods such as detergents, food stuffs, cosmetic products and pharmaceuticals' (SOCTA, 2013: $\left.11^{7}\right)$. The SOCTA frames these issues in the context of the potential economic, health and environmental harms for EU citizens. Hence, the need to disrupt 'organised crime groups' involved in the distribution and production of counterfeit goods that violate food regulation has been put forward as a primary response (see The Council of the European Union, 2013: $4^{8}$ ). Framing food fraud in these terms provides opportunities and justifications for governments and law enforcement authorities to obtain consensus around the need to increase resources, improve international cooperation, and so on, to 'fight' such threats, which nevertheless remain elusive (see Edwards and Levi, 2008). Actual and proposed policy responses have identified food businesses as integral to improving robustness. Such responses are designed to protect the markets from external, exogenous threats, rather than recognising the internal, endogenous cultural and structural conditions and market dysfunctionalities in the food system that are conducive to fraud. Following the horsemeat scandal across Europe, the EU produced a five-point action plan for

\footnotetext{
${ }^{7}$ https://www.europol.europa.eu/content/eu-serious-and-organised-crime-threat-assessment-socta

${ }^{8}$ http://www.consilium.europa.eu/uedocs/cms_data/docs/pressdata/en/jha/137401.pdf
} 
the short, medium and long term ${ }^{9}$. The Plan identified the need for: improved synergies between authorities and cross-border information exchange; improved testing programmes of DNA and for 'bute'; better usage of horse passports; improved official controls, implementations and penalties (e.g. more punitive fines, unannounced inspections); and, more effective labelling rules on food provenance. These mechanisms are geared towards external actors and the 'usual suspects', rather than those integral to the food production process.

Such popular (and analytically weak) constructions communicate 'organised crime' as a highly organised, Mafia-type external threat that just exists 'out there'. Academic evidence indicates this is inaccurate as the concept of 'organised crime' is itself ill-defined (see Edwards and Levi, 2008) and its many conceptual inadequacies have been analysed elsewhere (see for example Levi, 2007; Paoli, 2002; Hobbs, 2013; Felson, 2006). The argument here is not that organised crime groups (however defined) are not or are rarely at the centre of food fraud. We recognise that such criminal networks of illegitimate actors can instigate and be heavily involved in food fraud whether in the UK, other European countries (e.g. such as the 'Agromafia' in Italy that have been involved in olive oil frauds ${ }^{10}$ ), or internationally (e.g. such as the adulteration by Chinese Mafia of baby milk ${ }^{11}$ ). In regions where organised crime is pervasive, this is more likely to be the case if the market is profitable, and vice versa. The key issue is that the common portrayal and over-emphasis of the integral role of organised crime groups directs attention away from the importance of legitimate market and industry actors to the functioning of food fraud, whether driven by external organised crime groups or occupational actors. In all food fraud cases, there is a necessary role of legitimate markets, structures, practices and actors that need to be understood. In this sense, clear structural relationships can exist between the involved internal and legitimate, occupational ('white-collar')

\footnotetext{
${ }^{9}$ http://ec.europa.eu/food/safety/official_controls/food_fraud/docs/memo-14-113_five-point-actionplan_en.pdf

10 http://www.cbsnews.com/news/60-minutes-agromafia-food-fraud/

${ }^{11}$ http://www.odt.co.nz/news/national/27929/organised-crime-behind-tainted-milk-pm-told
} 
actors and networks of external, 'illegitimate' criminal actors. These legitimate relationships will reflect business practice as many of these relationships are involved in day-to-day legitimate business. There is a considerable literature on business process management (see for example Brocke and Rosemann, 2015) that considers how the business process works and there are vulnerability studies of specific economic sectors and food is one such sector (see for example Crescimanno et al.,2014). One common role is that of the broker. Brokers exist in all aspects of business to facilitate the flow of information, goods and money between businesses. The same applies to illegitimate business practice (see for example Morselli and Roy, 2008; Brunisma and Bernasco, 2004).

Understanding the relationship between networks of those legitimately placed within the food industry and acting fraudulently and the market for adulterated food product is currently acknowledged to be poorly evidenced and under-theorised ${ }^{12}$. This research gap is problematic. Our research suggests that criminal action by legitimate actors in the food supply chain is not uncommon. This corresponds with research on fraud more generally as researchers since Cressey (1953) have shown that most professionals are already in a position to commit frauds by virtue of their legitimate jobs. The key question is to understand why some of these actors decide to engage in fraud and the conditions that are facilitative. Understanding food fraud as 'enterprise', we identify many common features between illicit behaviours for gain and the aims of legitimate business, where entrepreneurial, rather than vocational, objectives, are the primary purpose. Understanding 'crime as enterprise' in this way and analysing how it manifests within different (legitimate) market structures "is a necessary precursor to explaining how different traders apprehend the constraints and opportunities provided in these markets and thus why certain markets contract whilst others expand" (Edwards and Gill 2002:219).

\footnotetext{
${ }^{12}$ The interim Elliot Review (HM Government, 2013: 7) into food crime recognised the 'limited intelligence' to determine the extent of systematic criminality in the food chain, or the role of 'organised criminal networks', though the final Elliot Review (HM Government, 2014: 12) concluded the 'serious end of food fraud is organised crime'.
} 
It is the legitimate occupational positions (e.g. as meat processors or brokers), organisational settings (e.g. legitimate wholesalers or cutting plants within the supply chain) and business practices (e.g. buying and selling produce) that create criminal opportunities and provide 'ready-made' markets and networks through which to conceal illicit behaviours. Key features of such occupational/organisational deviance include: the likely offenders have legitimate access to the location where the fraud takes place; the likely offenders are spatially separated from the victims, the consumers further along the supply chain; and the actions of the likely offenders have a superficial appearance of legitimacy thus facilitating concealment (see Sutherland, 1983; Benson and Simpson, 2015: 101).

It is the organisation of food frauds rather than a concern with the nature of the offenders that informs our analysis. It is how motivated and cooperating offenders interact with suitable targets and criminal opportunities in the absence of capable guardians in particular settings that is critical (see Felson, 2006). How these interactions and settings are contingently shaped by wider socialstructural antecedents and contexts (see Edwards and Levi, 2008: 369) is also a critical element of our approach. For Levi, 'fraud - like all crimes - is the result of the interaction between motivated offenders, their skill sets, and the opportunities presented by victims and by those entrusted with controlling risks' (2012: 8). So, '[a] key challenge for developing our understanding of illicit enterprise is to pursue a more qualitative interpretation of the actual decision-making processes engaged in by illicit traders' (Edwards and Gill 2002:218). There is not space to address all aspects in-depth, however, we use this analytical framework to guide our analysis of how structural conditions facilitate the creation of criminal opportunities for food fraud. This approach enables us to integrate the often discrete literatures on white-collar crime and organised crime in an attempt to understand the organisation of food fraud and the dynamic of criminal opportunity and legitimate actors. Focusing on 'organisation' allows us to circumvent the conceptual 'dangers of drawing tight lines 
around organised or corporate crime based on the characteristics of either offences or offenders' (Croall, 2010: 693).

The Sporty Pop Case Study: Soft drinks in Europe

To demonstrate these dynamics, we present findings from an analysis of fraud in the soft drinks market in a European jurisdiction. The case was one that had made significant demands on the regulator's resources. The regulator has responsibility for food safety and within the agency there is a specialised unit that has responsibility for the investigation of food incidents. There is a close association between this unit and law enforcement, welfare agencies, tax and revenue and the agricultural sector regulator. We provided an analysis of the case, we were allowed access to the case files, and we held in-depth discussions with the two lead investigators in the case. Using business databases, we were able to explore company records and the relationships of the various companies involved in the case. The regulator wanted to utilise our analysis in understanding the organisation of criminal behaviours at the centre of the fraud. A non-disclosure agreement was signed with the regulator in order to allow access to the relevant case data. This agreement allowed us access to the details of the investigation and the interviews with the investigators allowed us to clarify and explore the case in detail. We were not able to discuss the case with the relevant commercial interests and we did approach the industry representative group but were kept at 'arms length' with, what appeared to be, a determination to reveal, even at the most general level, the contractual relationships of production that exist within the soft drink industry. As Tombs and Whyte (2015: 31) noted, '[t]he corporate customer is invariably the principal actor in a supply chain and as such is able to dictate the conditions of production, through contract, within those chains' and so recognising such market (dys)functionality is essential to understanding the implicitly and explicitly constructed conditions for food frauds. 
The soft drink market remains a lucrative business despite consumption trends shifting towards healthier drinks. In Europe, the soft drink market has shown a compound annual growth rate of $2.3 \%$ between 2010 to 2014 (MarketLine Industry Profiles, Soft Drinks in Europe, October 2015). In 2014, the European soft drink market had a revenue of US $\$ 189.7 \mathrm{bn}$, reaching a market volume of 160.2 billion litres. The market is expected to continue growing by $2.5 \%$ in 2019 , with market volumes reaching 178.7 billion litres (MarketLine Industry Profiles, Soft Drinks in Europe, October 2015). Large multinationals dominate the European soft drink market - for instance, Coca Cola and Pepsico and they benefit from scale economies, strong brands and a full range of products, which in turn increases their market power. As consumers move to healthier drinks, there is space for new entrant products in niche markets such as functional drinks and those with purported nutritional benefits (MarketLine Industry Profiles, Soft Drinks in Europe, October 2015; The Grocer, Focus on Energy Drinks 2015). These new entrants will face fierce competition with market leaders who no doubt will engage in the healthier soft drink market, and will most likely acquire the successful products (MarketLine Industry Profiles, Soft Drinks in Europe, October 2015). Nevertheless, retailers are demanding more flexible order and delivery processes from soft drink companies and this increases the retailer power within the market as companies have to invest to improve their production efficiency albeit losing their pricing advantage.

The 'Sporty Pop' case occurs within this volatile market where margins are tight. In 2013 a European food regulator received information that there was a batch of tampered 'Sporty Pop' being distributed by companies and small retailers in the soft drinks market. The informant suspected this to be the case because the packaging used was not the same as that used at the official Sporty Pop UK production facility or of the official Sporty Pop manufacturing subcontractors. A potential food safety issue was recognised and an investigation was conducted. It was ascertained by the regulator that the fraudulent activity was concerned with the tampering of the 'Best Before Date' (BBD). The date had, at some point along the distribution chain, been changed in order to indicate a longer shelf 
life than originally printed on the bottle cap. The investigation discovered that there was a considerable penetration of the tampered product across the market. The tampered product was not confined to one specific region and crossed jurisdictional boundaries.

\section{Sporty Pop - the Squeezing of Residual Profit}

A large late date consignment of Sporty Pop was sold to a broker by the manufacturer. This broker sold the product to a Cash and Carry (CCA) that had a sister company (CCB) in the adjacent jurisdiction, located just over the border and trading under the same name. The Wholesaler and CCA and CCB were located in close proximity to each other. CCA and the wholesaler were next door to each other and $C C B$ is less than 10 miles from CCB, these were legitimate and unproblematic trading relationships. The initial broker(s) engaged to dispose of the Sporty Pop into the market sell large quantities, cheaply, to the Wholesaler. The broker disposes of all their stock quickly and at a profit. Profit is taken through volume, the profit on each individual unit of Sporty Pop is small, but because the wholesaler has taken considerable volume the broker can make a rapid return on the initial outlay. The wholesaler is also able to repeat this 'profit taking' exercise by selling the Sporty Pop on to Cash and Carry companies. The Cash and Carry company can turn over the money quickly by disposing of the Sporty Pop through their existing efficient distribution network. At this point no fraud has been committed. The splitting of the larger consignment by CCA into a number of smaller transactions and the distribution via the sister company (CCB) ensures market penetration. We categorised the outlets that sold the late date Sporty Pop and they were predominantly discount outlets charging the lowest price for their goods. These outlets sold a range of products including mops and buckets, hardware, sweets and soft drinks. Such outlets rely on quick sales so that each item returns a small profit. There were also mobile catering outlets and sports stadia, locations where perhaps only scant attention is paid to the BBD of the drink. The transactions that placed Sporty Pop into the market were not fraudulent, however there was considerable market 
penetration. The case also illustrates the practice of taking a small profit by relying on volume of sales to make a return.

The case file indicates another series of transactions with a market intermediary. This intermediary had a number of business interests, including haulage and packaging and had previous business interests in trading food. When these premises were raided a printer and packaging machine were found along with solvents able to remove ink. This intermediary was using a buy and sell website to dispose of the Sporty Pop. The intermediary had business networks, connections and knowledge to ensure product distribution functions across different stages of the market. The business networks of the intermediary mirror social networks as supplier-buyer relations are often trust-based and long-standing, rather than ephemeral and loosely connected. The critical issue is that the initial consignment of Sporty Pop released into the market was broken down into smaller packages via these existing business networks. These smaller packages of Sporty Pop were sold on so and the level of profit is now decreasing with each reduction in size. The practice of relying on profit from volume is now stressed to the point where taking a working profit is not feasible. For the buyers of the lesser amounts of Sporty Pop there is a problem in how to maximize the profit from product. As the profit becomes more elusive one strategy would be to tamper with the $\mathrm{BBD}$, so that the commodity moves from bargain basement stock to prime stock and commands a higher price.

Tampering with the BBD has a number of levels of complication. If we consider the crime scripts of the fraud it is labour intensive and requires certain equipment. Such a process comes with risks, as there is the potential for a 'whistleblower' or a disgruntled partner to talk to the authorities. There is a need for labour to unpack the bottles and each pallet contains approximately 240 bottles and so 20 pallets would be 4,800 bottles. The removal of the packaging and the legitimate BBD has to be done manually, using a solvent to remove the date, in order to preserve the labelling. A new BBD has to be printed onto the bottle and so an appropriate printer, one that is designed to print onto bottle 
caps, and ink is required. The bottles then need to be re-packaged and a packaging machine is necessary. It was the packaging that alerted the informant that the Sporty Pop was not authentic. Specialised equipment is needed plus a storage and packaging location. These resources are not acquired quickly and are too costly for a one-off operation, particularly where the return is minimal. The necessary resources are part of a legitimate operation where such activity can occur without suspicion. The resources required to tamper with BBD suggest that it is a common, embedded and habitual practice, rather than infrequent. The tampering occurs at the point of 'stressed profit'. There is nothing in the case file that suggests that the transactions undertaken by CCA or CCB are concerned with falsifying the BBD. Therefore, not all points of the market are equally vulnerable to fraudulent action. However, it is clear that this fraudulent behaviour is characterised by business duplicity and dishonesty within the market and the prime motivation is the opportunity for financial gain or pressures to meet cash flow needs.

The manufacturer placed Sporty Pop into the market in order to manage the excess created by optimum production. Once the product had been placed in the market there were no contractual controls over the sale of the drink in the market and the controls that exist at the prime level of the market are, it seems, absent at the bargain end of the market. The lack of contractual obligations removes one of the means by which the integrity of the drink is assured to the consumer. However, at the bargain level of the market the issue of the integrity of the BBD is not a significant issue for the commercial firms directly involved. There is a lack of 'guardianship' over the soft drink and so there are no controls that ensure its integrity. This lack of control means that the falsification of the BBD is low risk and if discovered the losses are low with little or no prospect of criminal charges. There are no formal controls within this level of the market and the lack of regulation and oversight leaves the market open to myriad forms of fraud.

The facilitating conditions of the fraud: over-production in congested markets 
Sporty Pop is a leading brand and found within many European markets targeting a 21-35 young professional demographic. The drink is marketed as enhancing performance rather than as a simple energy boost. The market for this type of product is not unproblematic for the producer; the lucrative nature of the sector has led to the emergence of number of different businesses and brands meaning it is congested with a number of similar products, some of which are sold as being healthier and less calorific. In general, this type of 'sports drink' is losing market share as consumers opt for healthier drinks with lower sugar content and growth in the sports drink sector appears to be hard to come by (see http://www.euromonitor.com/soft-drinks-in-the-united-kingdom/report). No doubt the introduction of a 'sugar tax' in the UK market will create further 'stress' in the sector. A significant outcome of this competitive and congested marketplace is a production pressure on manufacturers; they have to run plants efficiently that in most cases necessitates them organising production at near maximum output to make the plant cost effective (Pennings and Natter: 2001). One consequence of this over-production is that there is too much product for the market. Thus, it is the inherent nature of this market that creates business pressures across the sector. That is, endogenous features of the market create distress at certain points in the distribution of the oversupplied products. Such arguments may provide convenient 'rationalisations' or 'neutralisations' (see Sykes and Matza, 1957) and it becomes the challenge for investigators and prosecutors to establish when this is or is not a reasonable defence or mitigation for fraudulent behaviour.

\section{Brokering fraud and fraudulent brokers}

This over-production needs to be disposed of into the market and there are industry-accepted practices to do this. For example, 'brokers' exist that deal exclusively in late date product and 'overstock' that needs to be 'moved on':

'No matter what type of food products you have in overstock, calling Virrgo is the best way to sell it. Virrgo has interest in frozen meats, dried food products and the products that have gone out of date. Getting your money back on your initial investment is easier through this type of sale. Short sell stock is never a problem and frozen foods can be taken care of easily. Contacting Virrgo about the food products you received from the manufacturer as rejects is also a good idea' (https://www.clearancewholesale.co.uk/food-buyers accessed 20.10.15) 
Such companies, are one example of brokers within the food market, buying and selling into the various markets using different strategies. In legitimate business operations brokers play significant roles in ensuring that networks are innovative, creative and integrated (Morselli and Roy 2008). In the soft drinks markets, brokers are critical in maintaining the functioning of the market for wholesalers and manufacturers. What is more, such brokering provides a central service to markets in maintaining supply and ensuring a flow of product. Brokers in the soft drinks market offer mechanisms for increasing the competitive approach and so increase profitability. This type of brokerage occurs at a number of levels from large-scale brokerage to one-person brokerage operations. These are legitimate actors within the market, many of whom conduct a legitimate business, a few who may knowingly cooperate and collude with other market actors to distribute tampered products and some who may unwittingly be used to do so.

In the case of the Sporty Pop, a large quantity of the drink was made available by the manufacturer to the wholesale and late date market. As above, an efficient means of placing the product into the market is for the manufacturer to engage a broker and brokers are one of the 'unregulated nodes' in the network of market actors. The quantity of Sporty Pop to be placed into the market was considerable, however, once the manufacturer has made the transaction with the broker they have little or no further control of how the product is disposed of in the market and attempts to instigate such controls is disruptive to brokerage relationships (Food Manufacture, $2016^{13}$ ). For all of this it seems that the manufacturer does have to exercise some caution because they need to ensure brand integrity in their usual market, so the product needs to be brokered into a market segment that is differentiated from the standard market. This may be achieved by clauses in the contract with the broker. However, legitimate market actors are central to the organisation of the distribution of the late-date soft drinks into these low-level markets - while such business practices are legal, they

${ }^{13}$ http://www.foodmanufacture.co.uk/Supply-Chain/Food-supply-chain-seeks-transparency 
create opportunities for and are conducive to unscrupulous and criminal behaviour within the market. While the manufacturer is not directly involved in subsequent fraudulent behaviours, their business models facilitate such frauds.

\section{Concluding thoughts}

Our contention is that the common definition of food fraud is too prescriptive and fails to allow space to understand the role of different actors and the range of motivations. The uni-dimensional approach that constructs food fraud as simply motivated by economic motives is overly simplistic and lacking a detailed theoretical criminological analysis. The case study of Sporty Pop involving the tampering with BBDs demonstrates a number of the key features of food fraud that the economic motivation approach fails to explain.

The release of a large quantity of Sporty Pop onto the market occurred through a legitimate brokerage transaction. The Sporty Pop release is an element of solving the problem of overproduction, which is an outcome of the need to maintain manufacturing plant efficiency. This need to be efficient and economic in production creates a cascade of problems; how to release the product and maintain market integrity of the mainstream product, how to ensure no reputational damage and how to manage excess production. The brokering of the product into a different market segment manages to achieve some form of solution to each of the over-production problems. The release of Sporty Pop, however, presents a number of commercial difficulties for those involved in the distribution chain.

Primarily, as the soft drink travels along the distribution chain it becomes increasingly less profitable and becomes far removed from the manufacturer and any contractual controls on its distribution are near impossible to enforce. At this point there are strong incentives and motivations for fraud, in this case tampering with the BBD. There is a need to make some 'marginal' profit from the 
unprofitable Sporty Pop and this can be located within legitimate business transactions. In the Sporty pop case study all of the actors had a legitimate role within the distribution chain, even though some of the actors may have been located within the small profit margin sector of the food market. So, their purchase and sales of Sporty pop was not unusual or suspicious. One of the actors possessed the equipment to facilitate the tampering with the BBD and had access to distribution networks, again possession of Sporty Pop was not unusual or suspicious. However, the actors at this end of the market all engaged in the abuse or misuse of an otherwise legitimate business transaction and an otherwise legitimate social/economic relationship in the food system in which one or more actors undertakes acts or omissions of deception or dishonesty to avoid legally prescribed procedures (process) with the intent to gain personal or organisational advantage or cause loss/harm to others (outcome). Our analysis of the motivations of legitimate market offenders to first see and then 'make the most of' fraud opportunities that arise as a result of wider market and organisational conditions reinforces the conceptualising of these frauds within the framework of 'organisation'. The lack of a regulatory structure and oversight, plus the lack of contractual obligations and industry selfregulation in this area of the market provide ample opportunities for fraud with little risk.

The Sport Pop case study provides a useful heuristic to draw attention to some key features and conditions emerging across our research. However, there is no reason to suppose that such fraudulent activities are only confined to the soft drink market. For instance, in food markets where regulatory oversight is low and profit margins small, we see similar practices and motivations. There are a significant number of cases that suggest this is the case; the horsemeat case of 2013 strongly points in this direction and the recently published Food Crime Annual Strategic Assessment (FSA 2016) also lends support to this finding as does the recent results of Operation OPSON V (Europol 2016). One conclusion that can be drawn from this is that food markets are dysfunctional. However, 'dysfunctionality' can be misleading; for whom are these market conditions dysfunctional? The provision of cheap product, even if adulterated or tampered with, may be welcomed by particular 
consumer populations who perceive cut-price food as desirable especially if there is no harm to health. As Sporty Pop illustrates, market fragmentation and the existence of lower end markets of cheap product, is necessary for the 'functionality' of premium or higher end markets. What the practices in the Sporty Pop case study reflect is, we suggest, a culture of permitted and normalised deviancy within the market. It appears that the 'dysfunction' of the market is located in the manufacturer's blind-spot; not seen but a knowledge that 'something is going on'. There is a lack of concern because of market location and what we can describe as a normalisation and a routinisation of illicit practice. The 'Sporty pop' case also highlights the potentially repetitive nature of such practices. We see this elsewhere in our research, such as in incidents of olive oil adulteration where the relationship between production and supply is critical (see for example the Operación Lucerna, Operación Cloroil and Operación Colesterol olive oil cases in Lord, et al., forthcoming). These cases demonstrate similar features to the Sporty Pop case; market fragmentation and the need for lower end cheap product. A consequence of the fragmentation is that it undermines trust, confidence and integrity of the food system, and the dysfunctional aspects of the market impact on the consumer, regulator and honest players.

The Sporty Pop case study provides us with a greater insight into the motivations for food fraud and counters the generally held view that food frauds are committed by external actors involved in organised crime. By exploring how such frauds are organised we can see that fraud is one strategic response to stressed and dysfunctional markets.

\section{Funding}

This work was supported by the Economic and Social Research Council (ESRC) and the Food Standards Agency (FSA). 


\section{Bibliography}

Benson, M and Simpson, S (2015) Understanding White-Collar Crime, London: Routledge.

Braithwaite, J. (1984) Corporate Crime in the Pharmaceutical Industry, London: Routledge.

Brunisma, G. and Bernasco, W. (2004) 'Criminal Groups and Transnational Illegal Markets. A detailed examination on the basis of social network theory', Crime, Law and Social Change, 41:79-94

Cohen, Lawrence E. and Marcus Felson (1979). "Social Change and Crime Rate Trends: A Routine Activity Approach." American Sociological Review. 44:588-605.

Council of the European Union (2013) Council conclusions on setting the EU's priorities for the fight against serious and organised crime between 2014 and 2017, Justice and Home Affairs Council meeting Luxembourg, 6 and 7 June 2013.

Council of the European Union (2014) Draft Council Conclusions on the role of law enforcement cooperation in combating food crime, 15623/14

Cressey, D.R. (1953) Other People's Money, Glencoe, IL: The Free Press

Croall, H. (2007) 'Food Crime' in P. Beirne and N. South (eds) Issues in Green Criminology, London: Routledge. 
Croall, H. (2010) 'Middle-range business crime: rogue and respectable businesses, family firms and entrepreneurs' in F. Brookman, M. Maguire, H. Pierpoint and T. Bennett (Eds) Handbook on Crime, Cullompton: Willan Publishing, pp. 678-697.

Croall, H. (2012) ‘Food, Crime, Harm and Regulation’ Criminal Justice Matters, 90(1): 16-17.

Crescimanno, M., Galati, A. and Bal, T. (2014) 'The role of economic crisis in the competitiveness of the agri-food sector in the main Mediterranean countries', Agricultural Economics, 2014(2) 49-64

Doig, A. (2006) Fraud, Cullompton: Willan

Edwards, A. and Gill, P. (2002) 'Crime as Enterprise' Crime, Law \& Social Change 37: 203-223,

Edwards, A and Levi, M (2008) 'Researching the organization of serious crimes', Criminology and Criminal Justice, 8(4): 363-388.

Edwards, A., Hughes, G. and Lord, N. (2013) 'Urban security in Europe: Translating a concept in public criminology', European Journal of Criminology, 10(3): 260-283.

Ellis, D.I., Muhamadali, H., Haughey, S.A., Elliott, C.T. and Goodacre, R. (2015) ‘Point-and-shoot: rapid quantitative detection methods for on-site food fraud analysis - moving out of the laboratory and into the food supply chain' Analytical Methods, 7: 9401-9414.

European Parliament (2013) DRAFT REPORT on the food crisis, fraud in the food chain and the control thereof (2013/2091(INI), Committee on the Environment, Public Health and Food Safety 
EU Food Fraud Network (2014) Activity Report 2014, European Commission. Available here: http://ec.europa.eu/food/safety/docs/official-controls_food-fraud_network-activity-

report_2014.pdf

EUROPOL (2016) 'Largest ever seizures of fake food and drink in Interpol-Europol operation. (https://www.europol.europa.eu/content/largest-ever-seizures-fake-food-and-drink-interpoleuropol-operation)

EU SOCTA (2013) EU Serious and Organised Crime Threat Assessment, European Police Office.

Farberman, H. A. (1975) 'A Criminogenic Market Structure: the Automobile Industry', The Sociological Quarterly, 16(4): 438-57.

Felson, M (2006) 'The Ecosystem For Organized Crime', HEUNI Paper No. 26, The European Institute for Crime Prevention and Control, affiliated with the United Nations.

Hartung, F. (1950) 'White-Collar Offenses in the Wholesale Meat Industry in Detroit', American Journal of Sociology, 56(1): 25-34.

HM Government/Elliot Review (2013) Elliott Review into the Integrity and Assurance of Food Supply Networks - interim report, Crown Copyright.

HM Government/Elliot Review (2014) Elliott Review into the Integrity and Assurance of Food Supply Networks - Final Report, Crown Copyright.

Hobbs, D. (2013) Lush life: Constructing Organized Crime in the UK, Oxford: Oxford University Press. 
Levi, M (2007) 'Organized Crime and Terrorism' in M. Maguire, R. Morgan and R. Reiner (Eds) The Oxford Handbook of Criminology, $4^{\text {th }}$ Ed., Oxford: Oxford University Press.

Levi, M. (2008a) The Phantom Capitalists, Revised Edition, Aldershot: Ashgate.

Levi, M. (2008b) 'Organized fraud and organizing frauds: Unpacking research on networks and organization', Criminology and Criminal Justice, 8(4): 389-419.

Levi, M. (2012) 'Trends and Costs of Fraud' in A. Doig (ed.) Fraud: The Counter Fraud Practitioner's Handbook, Farnham: Gower.

Lord, N., Spencer, J., Albanese, J. and Flores Elizondo, C. (forthcoming) 'In Pursuit of Food System Integrity: The Situational Prevention of Food Fraud Enterprise'

Manning, L., Smith, R. and Mei Soon, J. (2016) 'Developing an organizational typology of criminals in the meat supply chain' Food Policy, 59: 44-54.

NFCU (2016) Food Crime Annual Strategic Assessment, Food Standards Agency/Food Standards Scotland.

Paoli, L. (2002) 'The Paradoxes of Organised Crime', Crime, Law and Social Change, 37(1): 51-97.

Passas, N. (2005) 'Lawful but Awful: "Legal Corporate Crimes"', The Journal of Socio-Economics, 34(6): 771-786. 
Pennings, E and Natter, M, (2001) Strategic Diversification and Capacity Utilization', International Journal of Production Economics, 72: $261-272$.

Shears, P. (2010) 'Food fraud - a current issue but an old problem', British Food Journal, 112(2): 198213.

Smith, R. (2004) 'Rural rogues: a case story on the "smokies" trade', International Journal of Entrepreneurial Behaviour and Research, 10(4): 277-294.

Spink, J. and Moyer, DC. (2013) 'Understanding and Combating Food Fraud', Food Technology, 67(1): 30-35.

Sutherland, E. (1983) White-collar Crime: the Uncut Version, New Haven, Conn.: Yale University Press.

Sykes, G.M. and Matza, D. (1957) 'Techniques of Neutralization: A Theory of Delinquency', American Sociological Review, 22: 664-670.

Tombs, S. and Whyte, D. (2015) The Corporate Criminal. Why corporations must be abolished, London: Routledge.

Vaughan, D. (1998) 'Rational Choice, Situated Action, and the Social Control of Organizations', Law \& Society Review, 32(1): 23-61. 
Vaughan, D (2007) 'Beyond Macro- and Micro-Levels of Analysis, Organizations, and the Cultural Fix' in H. Pontell and G. Geis (Eds) International Handbook of White-Collar and Corporate Crime, New York: Springer. pp. 3-24

vom Brocke, J. and Rosemann, M. (eds) (2015) Handbook on Business Process Management 1. Introduction, Methods and Information systems. $2^{\text {nd }}$ Edition. Heidleberg: Springer.

Williams, M. (2000) 'Interpretivism and Generalisation', Sociology, 34(2): 209-224.

Woolfe, M. and Primrose, S. (2004) 'Food forensics: using DNA technology to combat misdescription and fraud' Trends in Biotechnology, 22(5): 222-226.

Woolfe, M. and Primrose, S. (2004) 'Food forensics: using DNA technology to combat misdescription and fraud' Trends in Biotechnology, 22(5): 222-226. 